\title{
Introduction: Annemarie Schwarzenbach's Photographic Practice
}

\author{
SVEa Braeunert AND TANJA Nusser \\ University of Cincinnati
}

Annemarie Schwarzenbach (1908-1942) is known as a writer of novels, avid traveler, and photojournalist. Although she was a prolific photographer, up until recently it was more often than not the woman in front of the camera rather than behind it that was the focus of attention. ${ }^{1}$ Between 1933 and 1942, Schwarzenbach traveled extensively in Europe, Russia, the Middle East, India, the United States, and Africa, taking thousands of photos on her journeys, a selection of which she published in around 300 photo-reportages for Swiss Magazines, including the Zürcher Illustrierte, Basler National-Zeitung, Weltwoche, $A B C$, and the Neue Züricher Zeitung. Although not all photographs and negatives could be saved after her untimely death due to a bicycle accident in 1942, the Swiss Literary Archive (SLA) holds over 7,000 photographs that are archived as part of Schwarzenbach's literary remains.

Between 2006 and 2009, Memoriav: Verein zur Erhaltung des audiovisuellen Kulturgutes der Schweiz digitized 5,243 of her photos, and, in 2008, the SLA launched the first virtual exhibition, titled Am Ende aller Wege, including 100 of them, using a flash application. The SLA expanded on these efforts when, in 2017, they made roughly 3,500 of Schwarzenbach's photos available, linking them with Wikimedia Commons and opendata.swiss. ${ }^{2}$ The digital opening of the archive as well as a relaunch of the application Am Ende aller Wege / Au bout de tous les lointains: Annemarie Schwarzenbach Reisen / Voyages 1933-1942 in 2020, which now integrates all images, was a major impetus for us to put together this special issue of Monatshefte on Annemarie Schwarzenbach's Photographic Practice. ${ }^{3}$ Its preparation coincided with the exhibition Aufbruch ohne Ziel: Annemarie Schwarzenbach als Fotografin at Zentrum Paul Klee in Bern, which ran from September 2020 until January 2021 (Zimmer and Waldmeier). Both the exhibition and this special issue testify to an increasing awareness of the importance of Schwarzenbach as a photographer whose oeuvre and practice are situated at the intersection of various discourses. These discourses position her photos not

Monatshefte, Vol. 113, No. 3, 2021 
only as documents of her time but also as aesthetic explorations of sociohistorical, artistic, and media-specific questions.

With Annemarie Schwarzenbach's Photographic Practice, we hope to raise interest in her photographic oeuvre and broaden the contexts in which it is perceived and discussed. Taking the images seriously and not treating them as mere illustrations of her writings or her life means situating the photographs in their contemporaneous discourses, tracing their references to art and media history, and discussing them vis-à-vis Schwarzenbach's multifaceted practice, which can be described as oscillating between fixation and mobilization, entailing different kinds of writing, taking images, archiving, and moving around. Honing in on the connections and implications between writing, traveling, and photographing, Katharina Sykora has spoken of "einer sprachlichen und visuellen Doppelbegabung Annemarie Schwarzenbachs," although she notes that Schwarzenbach approached the two media differently: "Während sie in Bezug auf ihre schriftstellerische Arbeit [...] von Anfang an einen künstlerischen Anspruch hatte, entwickelte sie die Fotografie fast beiläufig im pragmatischen Zusammenhang journalistischer Tätigkeit" (Sykora, "Ausser Kurs (2001)" 209). The observation corresponds with Schwarzenbach's positioning of herself as first and foremost a writer. In a 1939 interview, she said:

Warum bin ich Schriftstellerin geworden? Denn es gibt noch andere Berufe. Zuerst wollte ich General werden, dann Pianistin (woran mich ein ... Schreibkrampf im richtigen Augenblick hinderte), dann studierte ich Geschichte, dann versuchte ich mich als Assistentin auf archäologischen Expeditionen. Die Liste ist nicht etwa vollständig, aber ich will niemanden zwingen, sich alle Inkonsequenzen meiner Vergangenheit anzuhören. Und zu meinem eigenen Trost füge ich hinzu, dass ich trotzdem immer geschrieben habe - tatsächlich immer. (Schwarzenbach, "Interview ohne Reporter" 12)

Nevertheless, even though Schwarzenbach positions herself as a writer, her reportages hint at a more complex constellation. During the 1920s, the photoreportage had established itself as a new form of reporting, which allowed for stylistic experiments and, due to a lack of conventions, gave self-declared amateur photographers such as Schwarzenbach the opportunity to publish their work and establish themselves as journalists. Furthermore, it promised, even more than other forms of journalism, a truthful and objective depiction of reality-not least because it combined text and image to make sociallyengaged arguments. The photo-reportage hence allowed Schwarzenbach to work with both media simultaneously, thereby developing a style that differed from the more poetic, hermetic, and at times self-centered, subjective style of her novels. The result is an oeuvre that is admirably broad, as it intertwines different cultural texts, including literary and journalistic writings as well as journalistic, touristic, and private photographs, often revisiting an event or 
observation in order to aesthetically rework it in different media and textforms. As such, it is an oeuvre that offers various entry points for reading, looking, and creating meaning.

To do justice to this oeuvre, an interdisciplinary approach is necessary, and we are delighted to have found authors from across different fields, including German Studies, Art History, Media Studies, Curation, Archival Studies, and the Digital Humanities whose 'case studies' show different approaches to Schwarzenbach's photographic oeuvre. We have asked each of them to engage with Schwarzenbach's photographs by selecting one image and taking it as a point of departure to develop their arguments, situating the image in a constellation with other images, or texts, materialities, and discourses. While a primary goal of the special issue is to focus on Schwarzenbach's photographs and direct attention to the vast archive of images that has recently become available online, our approach of looking at Schwarzenbach's photographic practice situates her images in correspondence with other media, including different forms of texts and archiving that Schwarzenbach engaged in herself during her lifetime or that were undertaken by archivists, scholars, and curators posthumously. Naturally, this also means that the archive itself comes into question as well as the different affordances, legibilities, and obstinacies its analog and digital forms hold.

The photos and topics discussed in the following six essays present a selection that highlights crucial aspects of Schwarzenbach's photographic practice. Geographically, the essays focus on Eastern Europe and the Soviet Union (Arndt and Dvorakk), Scandinavia (Wagner), the U.S. South (Felt and Kick), and the Middle East (Natlacen). Thematically, they home in on different archival logics (Dvorakk, Felt, and Wagner), situate Schwarzenbach's work in the art historical context of its time (Arndt, Dvorakk, and Felt), lay out a framework for an intersectional reading of her visual practice (Kick and Felt), and discuss her approach to and depiction of different cultures (Natlacen). What is missing from this selection are aspects such as a critical analysis of the photographs she took in Africa and their participation in colonial ways of seeing; a discussion of the importance of landscape, including but not limited to Schwarzenbach's fascination for the desert, oceans, and mountains, including the various photos she took of the alpine landscape in her homeland Switzerland (A-5-06/308; A-5-07/095; A-5-18/031), which are often more private in nature and were not intended for publication (A-5/08/145; A-5-08/177; A-5-08/234); her incessant return to ships, harbors, and sailors (A-5-10/023; A-5-17/063; A-5-23/135), and to her car; her remarkably early interest in the industrial impact on nature and the environment (A-5-10/096; A-5-10/194; A-5-17/193); and her keen eye for architecture, structures and spaces (A-5-10-187; A-5-17/042; A-5-17/082), which also shows in her dealing with the Nazi's rise to power by documenting the geometrical lines of symbols and parades in Gdansk and Austria (fig. 1); and, last but not least, a 


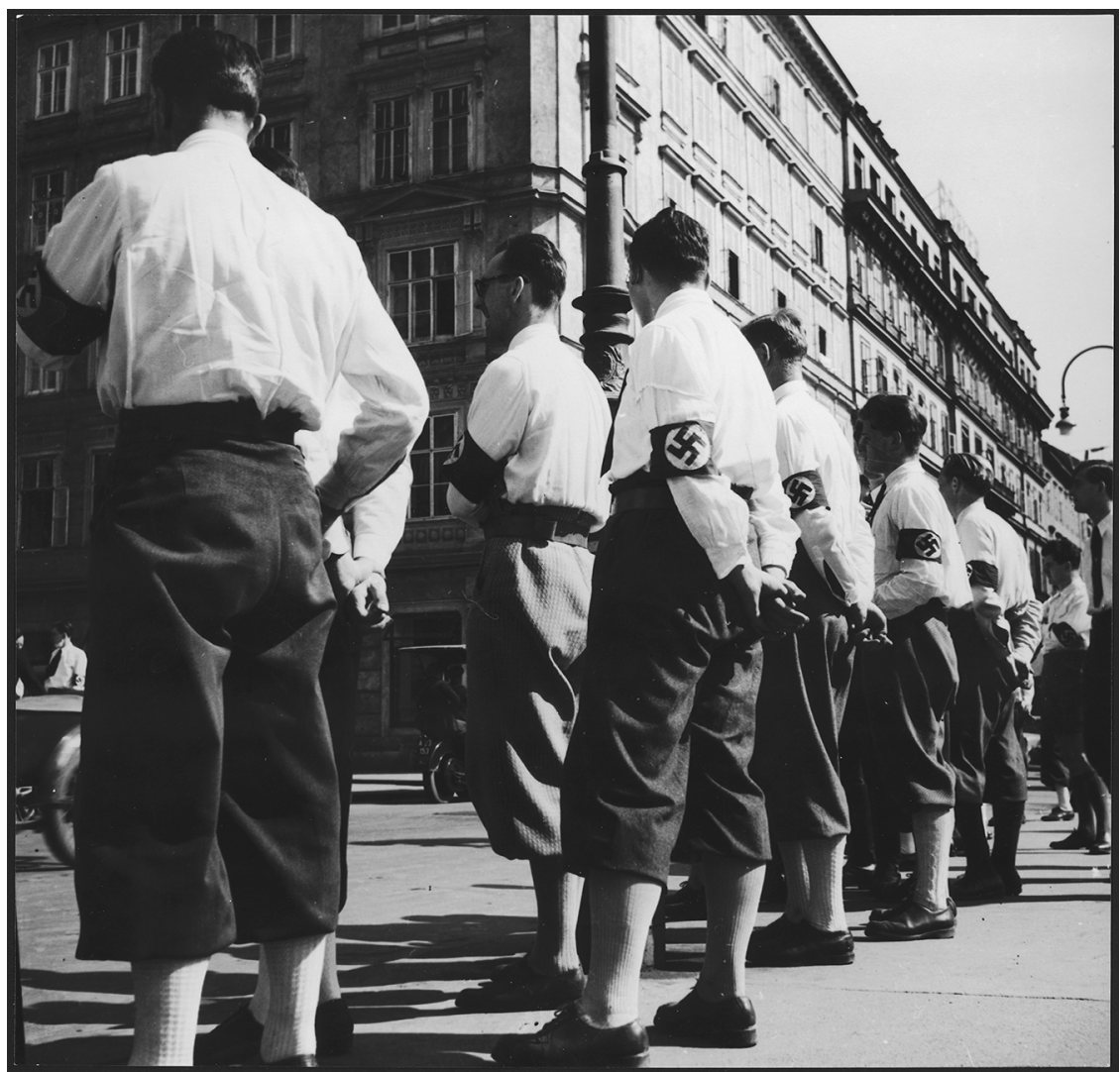

Fig. 1: Annemarie Schwarzenbach: Österreich, Salzburg: Menschen (1938).

Schweizerisches Literaturarchiv, Nachlass Annemarie Schwarzenbach,

Schweizerische Nationalbibliothek Bern, SLA-Schwarzenbach-A-5-18/021.

stereoscopic view that breaks through the suspiciously neat distinction between the supposedly private and the travel photographs, unearthing connections between motives and aesthetics. We hope that this special issue will draw further attention to Schwarzenbach's archive and these additional areas for investigation.

\section{Discourses: Modernism and Colonialism}

In the following, we want to offer a framework for the essays in this issue and for the research on Schwarzenbach's photographs more generally by situating them in mainly two discourses: modernism and colonialism. Taken together, they allow us to circumscribe an ethico-political friction we see in 
her oeuvre that oscillates between the visual and artistic appropriation of other cultures on the one hand, and on the other photographic engagement, critical reflection on her own positionality, and cultural awareness. It is a framework that takes into consideration both an aesthetics of production and an aesthetics of reception, detailing Schwarzenbach's working conditions while situating them in two of the defining discourses of her time. The camera and the car stand at the beginning of such an approach, because not only are they foundational for Schwarzenbach's practice, enabling her photographic journeys in the first place, but they are also indicative of her (implicit and explicit) participation in the discourses, aesthetics, and epistemes of modernism and colonialism.

The 1920s saw the mass-production of lightweight, small-range cameras such as the Leica (available since 1925) and the Rolleiflex (available since 1929), both of which were used by Schwarzenbach (Melone; Sykora "Von sich aus ins Weite"; Wiegand-Stempel). They made taking pictures on the go feasible, and, together with the car, Schwarzenbach's preferred mode of transportation, mobilized the production of images. A number of images in the archive combine the two by capturing the car in the photographic frame (fig. 2). The car signals agency that comes with having sovereignty over one's journey; it stands for (Western) modernism and exploration; and it has been interpreted as Schwarzenbach's alter ego (Wichor 163; Sykora, "Ausser Kurs (2001)" 226). Yet, besides serving quite literally as a mode of transportation between worlds, the car is also a medium of encounters and a translator. This becomes evident on the one hand in its status as a protagonist, passing borders and other demarcations; on the other hand, the car serves as a meeting ground between people and cultures. It is remarkable how many of the images in the archive show people leaning against the Ford or surrounding it (A-5-03/074; A-5-05/075; A-5-21/124; A-5-22/039). Taken together, camera and car thus suggest that modern technology can serve to overcome boundaries and forge new relationships with the world and the people inhabiting its various places, while allowing oneself to critically question one's own position in the context of these encounters and the media and dynamics underlying them.

Yet, these encounters take place in a late-colonial context, prompting Martin Waldmeier to describe Schwarzenbach's photographs as "späte Dokumente einer europäisch-kolonialen Weltordnung [...], die mit dem Zweiten Weltkrieg unwiederbringlich verschwand" (Waldmeier 20). This is painfully evident in Schwarzenbach's late photographs from Africa, which exemplify the ways in which photography was part of colonial endeavors through visual othering (e.g., Hight and Sampson) and by using photography to 'capture' subjects, turn them into objects, and claim ownership over them (A-5-25/027; A-5-25/147; A-5-25/263). ${ }^{4}$ Or as Bronisław Malinowski infamously put it: "Photographiert, Besitzgefühl: Ich bin es, der sie beschreiben oder erschaffen wird" (Malinowski 127). It is a sentiment also underlying the 


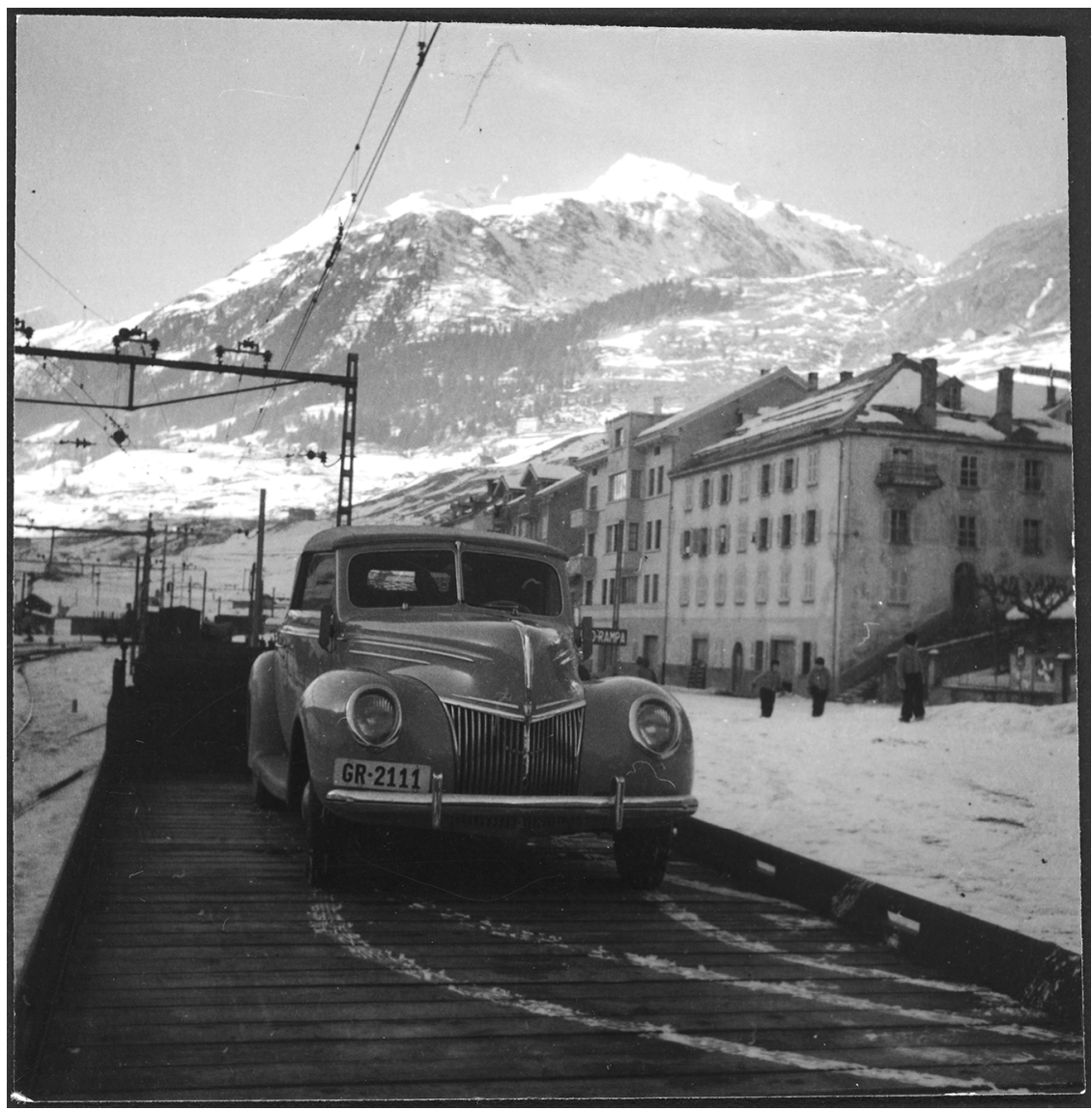

Fig. 2: Annemarie Schwarzenbach: Schweiz, Airolo: Ford (1940). Schweizerisches Literaturarchiv, Nachlass Annemarie Schwarzenbach, Schweizerische Nationalbibliothek Bern, SLA-Schwarzenbach-A-5-23/175.

collection of cultural artifacts and the anthropological quest to document other cultures by applying a seemingly objective stance (Heidemann). Similarly, some of Schwarzenbach's photographs from Turkey, Iraq, Persia, and Afghanistan adhere to the styles and stereotypes of orientalist genre paintings and orientalist imaginations more generally, including an idea of the Middle East as an irrational, mystical place and an image of the landscape as empty and devoid of people (A-5-02/059; A-5-03/092; A-5-04/021). ${ }^{5}$ Schwarzenbach's perception - what she 'sees,' discursively and visually frames, and documents in these places-is presupposed by existing perceptions and discourses, often adhering to a stereotypical and exoticizing rhetoric. At the same time, the status of her images as travel photographs makes a claim for their 
documentary character, turning the photo-reportage into an ideological medium influencing the perception not only of what foreign countries look like but what counts as 'foreign' and 'Other' in the first place, including the repetition of imagery ripe with stereotypes.

Connected to the colonial setting of her travels and the exoticizing rhetoric of her photographs (Bettray) is Schwarzenbach's interest in archeology and anthropology. Numbers of her photos visually archive archeological finds (Belichtete Vergangenheit: Archäologie and Fotografie). Heidy Margrit Müller shows how Schwarzenbach's photographs are influenced by or depict similar motifs as images made by earlier female archeologists like Jane Dieulafoy and Gertrude Bell who illustrated their archeological publications as well as their travel writings with their own images (Müller). This means part of Schwarzenbach's photographic work can be perceived as a quasiarcheological attempt to archive historical materials and objects and to conserve them beyond the photographic moment (A-5-04/049; A-5-07/138; A$5-26 / 167)$. Bound up with questions of cultural heritage, ownership, and definition, photographing archaeological finds is a practice that extends photographic time through the time condensed in the object, which itself can be seen as a photograph of sorts. An image of an archaeological object is thus a photo of a photo, doubling the photographic constellation; and it asks viewers to consider the image(s) in front of them as embedded in the long durée of histories.

While the archaeological photos point back in time, they are nevertheless engagements of and with the contemporary moment, which is foregrounded in Schwarzenbach's use of modernist aesthetics (fig. 3). Important influences include the Bauhaus-inspired agenda of a New Vision photography championed by László Moholy-Nagy in publications such as Malerei. Fotografie. Film (1927) and the exhibition Film und Foto which he curated in 1929. Optical experiments such as double exposures, extreme angles, and contrasts of light and shadow as well as dynamic compositions are hallmarks of New Vision photography meant to highlight the machinic origin of the images and to express a decisively modern and potentially revolutionary spirit. Tightly connected to the Bauhaus program of New Vision is Soviet constructivism, put forward by artists such as El Lissitsky and Alexander Rodschenko. In her essay in this issue, Elisaveta Dvorakk argues that traces of Soviet constructivism can be found in Schwarzenbach's photographic compositions from 1934, which suggest that Schwarzenbach's understanding of photography as a critical medium of social engagement cannot be reduced to her later encounter with the images of the U.S. Farm Security Administration (FSA). Rather, it dates back to what she saw in Moscow two years earlier, including the avant-garde medium of film.

The aesthetic of the FSA photographs is connected with names such as Esther Bubley, Dorothea Lange, Walker Evans, Marion Post Wolcott, Ben Shahn, and John Vachon. The FSA was put in place by US President Franklin 


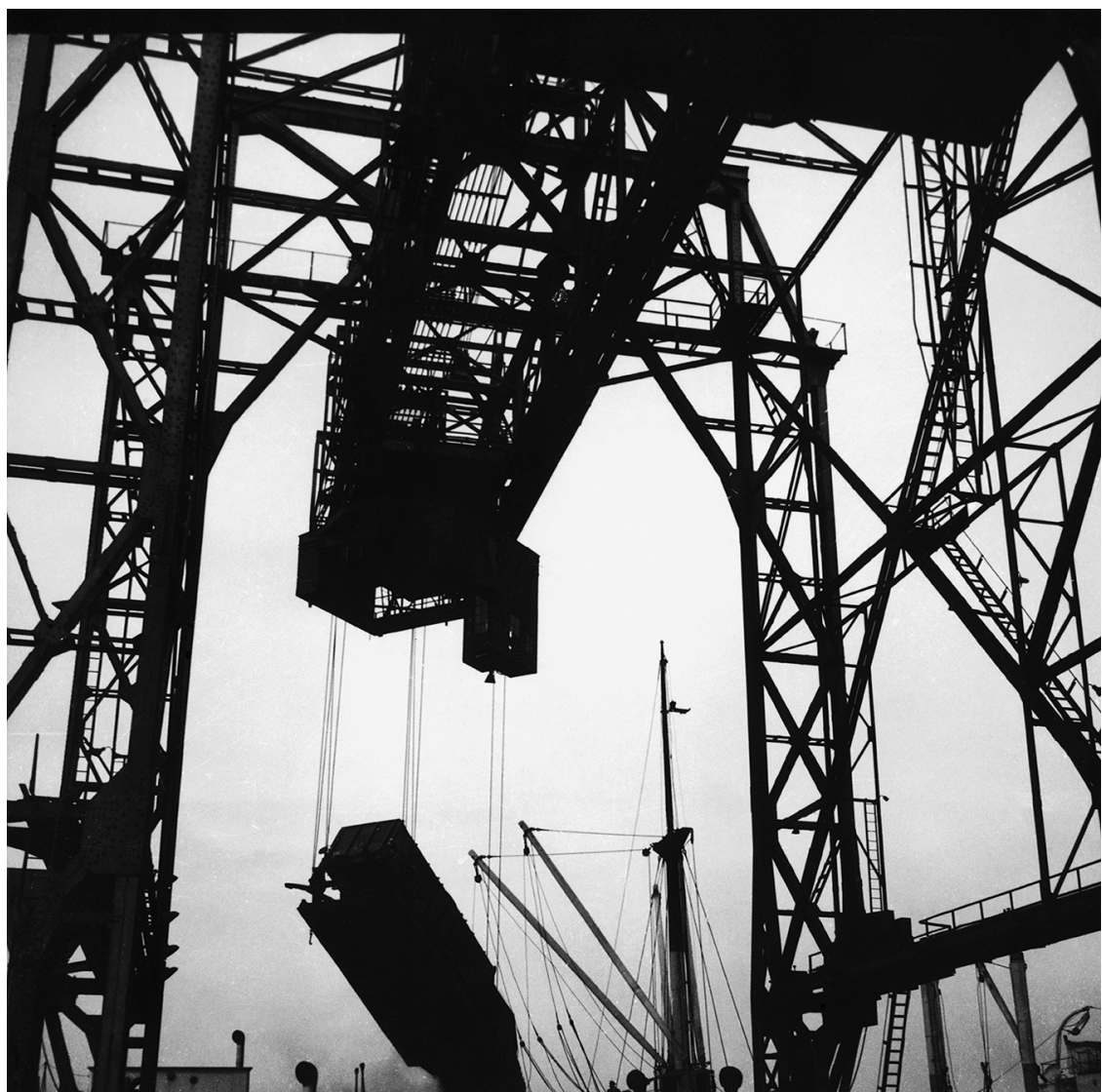

Fig. 3: Annemarie Schwarzenbach: Polen, Gdyna (Gdingen, Gotenhafen): Kohlenwaggons (1937). Schweizerisches Literaturarchiv, Nachlass Annemarie Schwarzenbach, Schweizerische Nationalbibliothek Bern, SLA-Schwarzenbach-A-5-13/094.

D. Roosevelt as part of his New Deal Program to combat poverty following the Great Depression. ${ }^{6}$ The photographic unit developed a realism that aimed to stir empathy in viewers and engage them politically. Schwarzenbach subscribed to the FSA program when outlining photography as a socially and politically engaged medium that can create awareness through its documentary character, as she argued in "'Bilder als Dokumente': Die Zeitschrift 'Life"” where she writes: "Und wenn 'Bilder als Dokumente' auch noch kein Urteil enthalten, so wird das Publikum doch auf Probleme aufmerksam gemacht" (Schwarzenbach 15). Schwarzenbach followed this ideal of a socially engaged photography in her reportages when she portrayed people at the 
margins of visibility, visually highlighting how race, gender, and class factor into the perception and representation of the disadvantaged and disenfranchised (Bergmann; Bettray; Decock; French; Henke).

The frameworks of modernism and colonialism we have only briefly laid out here as two options for reading Schwarzenbach's photographs present us with the dilemma of dealing with an oeuvre that oscillates between images that can be traced back to exoticizing colonial imaginations and a socially conscious photographic practice, both of which are tied to conflicting documentary forms. While the colonial framework puts an emphasis on the production of knowledge, practices of control, and (visual) domination, the modernist framework brings to the fore aesthetic registers tied to the hope of a progressive political agenda and democratization. As John Tagg argued in his influential The Burden of Representation: "The emergence of photographic documentation and what Barthes sees as the photograph's 'evidential force' were bound up with the new discursive and institutional forms, subject but also exercising real effects of power" (Tagg 7-8). Schwarzenbach's photographic practice needs to be seen in light of these systems of knowledge and power, enabled by a privileged European perspective and sustained by colonialism. The images that result from this constellation can at times be conflicting and complex, presenting positions that waver between an unthinking repetition of a visual vocabulary tied to Eurocentric and colonial archives, a modernist understanding of structures and forms, and a social-humanistic engagement.

Folded into these lineages and cutting through the different realms of knowledge is the archive, famously defined by Michel Foucault as "the law of what can be said, the system that governs the appearance of statements as unique events" (Foucault 129). Following Heath Massey's argument, archives in the Foucauldian sense are "a set of rules or norms determining what can be said or written," and therefore "the archive limits discourse" (Massey 82). In the context of colonialism, archives have been and continue to be powerful tools of domination and restriction. In the way they catalog, name, and give each collected material a place within an order of things, they produce hierarchies, exclusions, and take the material out of context, resulting in fragments presented as wholes framed by Western systems of knowledge and practices of presentation. And yet, the latency of the archive may also turn its meanings around, drawing on collections to unearth forgotten objects and stories, and to reclaim, review, and rewrite histories.

\section{Archives: Photograph, Index Card, and Series}

In the following, we trace the potential contained in the archived photographs by looking at a selection of them, starting with a single image that is particularly evocative in its simultaneous address of photography and Orientalism, 
indicated by its title Persien: Fotografieren (1935). The photo is a low angle shot depicting two male figures standing in the Persian desert, their bodies slightly turned to the right. The man on the right, dressed in European clothes who, according to the SLA's description (A-5-06/003), might be Schwarzenbach's French husband Claude Clarac, is depicted in the act of photographing. The camera is fixed on a tripod, and his head disappears behind the black cloak of the camera. What he is about to photograph is outside of the frame. To his left is a young indigenous man wearing a Phalavi hat and suit. ${ }^{7} \mathrm{He}$ is holding on to the string of the camera case, which stands on the ground next to him; and he is looking at Schwarzenbach, who took the photograph. Disregarding gendered conventions which would display the woman for the male

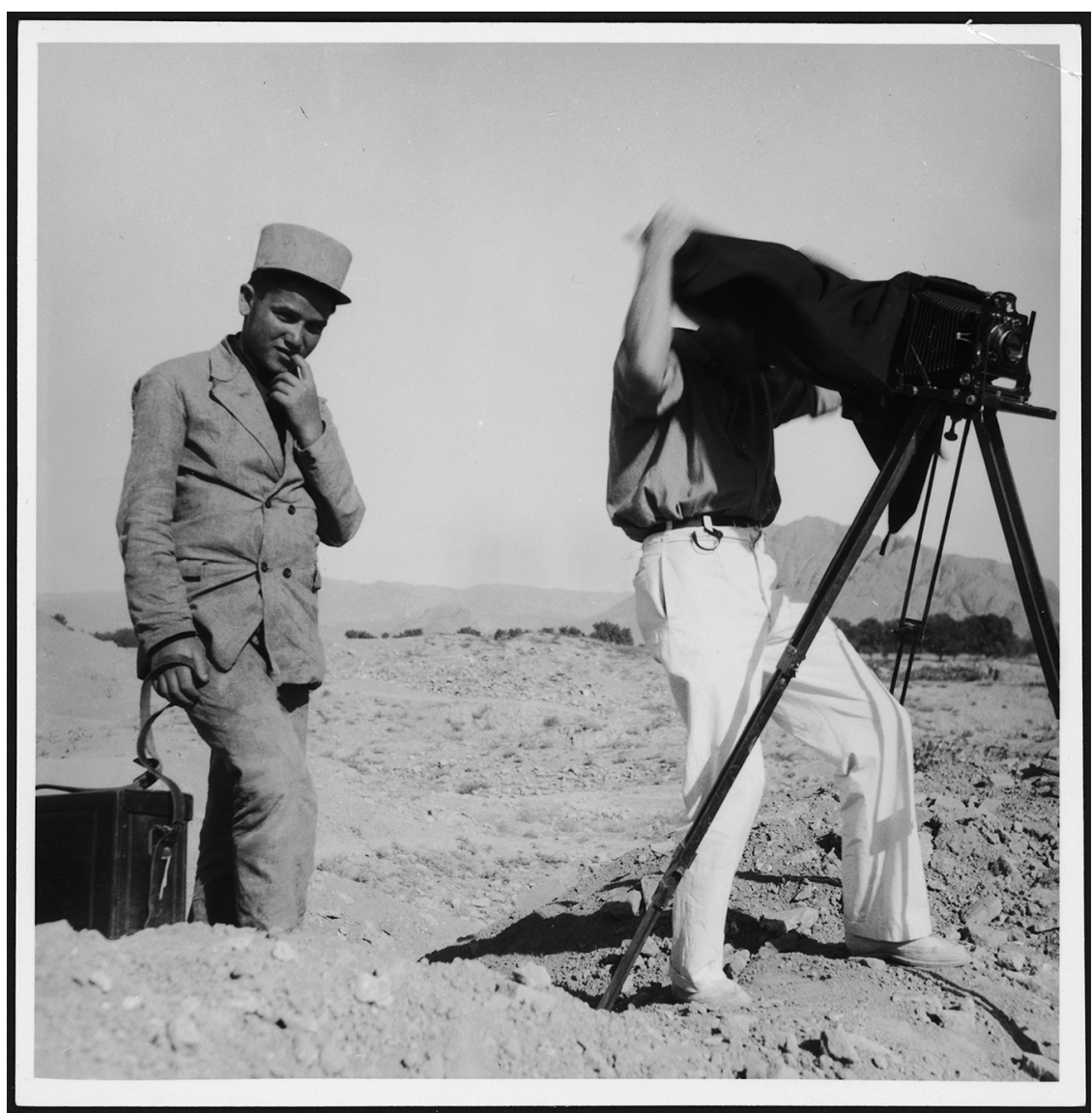

Fig. 4: Annemarie Schwarzenbach: Persien: Fotografieren (1935). Schweizerisches Literaturarchiv, Nachlass Annemarie Schwarzenbach, Schweizerische Nationalbibliothek Bern, SLA-Schwarzenbach-A-5-06/003. 
gaze, she, the female photographer, casts an image of two male models representing two conflicting scopic regimes: the European claim to a mediated, distanced view on the one hand, and the indigenous claim of the right to look (back) and be seen on the other.

The photographic situation displayed here is interesting because gender and race intersect in astonishing ways. The European photographer is shown in the possession of the power of the gaze, emphasized by the fact that he is able to see without being seen. Shielded from the camera that is pointed at him, his figure stands in for a racial discourse in which white is a non-color and unseen. The indigenous man, by contrast, is exposed. His image is snatched by another European photographer, Schwarzenbach, who stands outside of the frame and takes his image, marking him as Other. ${ }^{8}$ Simultaneously, though, he is portrayed in a more personal way than the cloaked European, as the index finger in his mouth makes for a gesture wavering between playfulness, inquisitiveness, and shyness, and, most importantly, his face is turned towards Schwarzenbach and the viewer, claiming his right to look and to be seen. Looking at Schwarzenbach, the indigenous man's gaze too is directed at something, or rather someone, outside of the frame. As a result, the subject of photography is always elsewhere in this image, centering and decentering attention and causing a constant slippage in meaning. And indeed, no matter how central the two men are in revealing the ways in which the colonial system is based on gendered and racialized gazes, they do not take center stage. For in the center of the image is the Persian landscape, a sandy, flat surface in the fore- and middle ground and some bushes and low-level mountains in the background. It creates the impression of an empty center and thereby crafts an image that, in its supposed emptiness, is steeped in female colonial phantasies, situating the participants in a techno-natural setting of ever-shifting connotations.

Persien: Fotografieren has allowed us to review the ways in which Orientalism and photography are connected by focusing on a single image. In doing so, we followed the cue we have given the authors of the present issue, which was to develop their arguments starting with one photograph from the archive. Nevertheless, just as we encouraged each author to discuss their key image in connection with other images, texts, materialities, and discourses, we too want to go beyond the single image and apply two standard practices for working with images that not only derive out of the discipline of art history but, more importantly, come directly out of Schwarzenbach's practice: the dual 'projection' of two images side by side, and the series, enabling the unfolding of narratives across multiple images and encouraging repetition as well as selection deriving out of the collecting logic of the archive.

The first one, the juxtaposition of two photographs, is realized by Schwarzenbach in her use of index cards. As Sykora points out, Schwarzenbach followed an "Ordnungsprinzip, nach dem sie die Kontaktabzüge ihrer 
Aufnahmen in Bildpaaren zusammenstellte, auf Karteikarten montierte und handschriftlich kommentierte" (Sykora, "Von sich aus ins Weite" 134). Some of these index cards (albeit only their fronts) are available in the online archive. Looking at them demonstrates Schwarzenbach's "ausgeprägten Sinn für die ästhetische Aussagekraft ihrer Fotografien, nicht nur was die Einzelbilder betrifft, sondern auch ihre Zusammenstellung. Was sie den Zeitschriften lieferte, war daher nicht weniger als eine eigene fotografische Syntax und Semantik" (ibid.). The majority of index cards consists of two photographs, either fixed parallel to each other or in a slight vertical shift. Date, location, the number of the role of film used, and a short description are added often, though not consistently. There is usually handwriting and typewriting, sometimes also a note added later by the archive; sometimes, the stationary of the local hotel is used (Dvorakk, Wiegand-Stempel). The result is a conscious montage whose effect is built on what happens between the images (as well as between text and image). There are two instances we find particularly interesting.

The first has to do with visual similarities, which only become discernable once images are juxtaposed with each other. On an index card from Afghanistan, we see on the left side a photograph of a boy and a man making "'Mast' (Sauermilch)" (A-5-19/186) in a goat skin (fig. 5). Shape, color, and visual placement of the goat skin show a striking similarity to the slightly lower image on the right: "Unser Ford in der 'Garage' in Herat" (A-5-19/ 186). The hood of the car is open, a man bends over the engine, while two other men lean against the wall in the background. Minimally offsetting the two photographs, yet displaying them side by side with ample room between them, two readings become possible: one highlights modern progress as asynchronous, juxtaposing modern technology and traditional craft, while the other sees their simultaneity, stressing their existence side by side as techné, or an applied form of knowledge production. ${ }^{9}$

The second effect that Schwarzenbach's index cards have is cinematic, as they turn still photographs into moving images. ${ }^{10}$ This effect is achieved by appropriating cinematic techniques such as 'zooming in,' or working with shots and counter-shots. The first can be seen on an index card combining two photographs of a group of nomads riding on camels. While the image on the left is an extreme long shot situating them in the landscape, the image on the right shows them in long shot, photographed from below. The handwritten note comments poignantly: "Sie nähern sich" (A-5-19/142). The second technique is discernable when Schwarzenbach shows a window once from the inside and once from the outside (A-5-19/026), or when she arranges a group of working women in a way that they are facing each other, each image complementing the other (fig. 6). Understanding the photographs on the index cards as moving images is intriguing, because it translates Schwarzenbach's practice of fixation and mobilization into a method for watching her photographs, allowing viewers to look at these images and their arguments anew. ${ }^{11}$ 


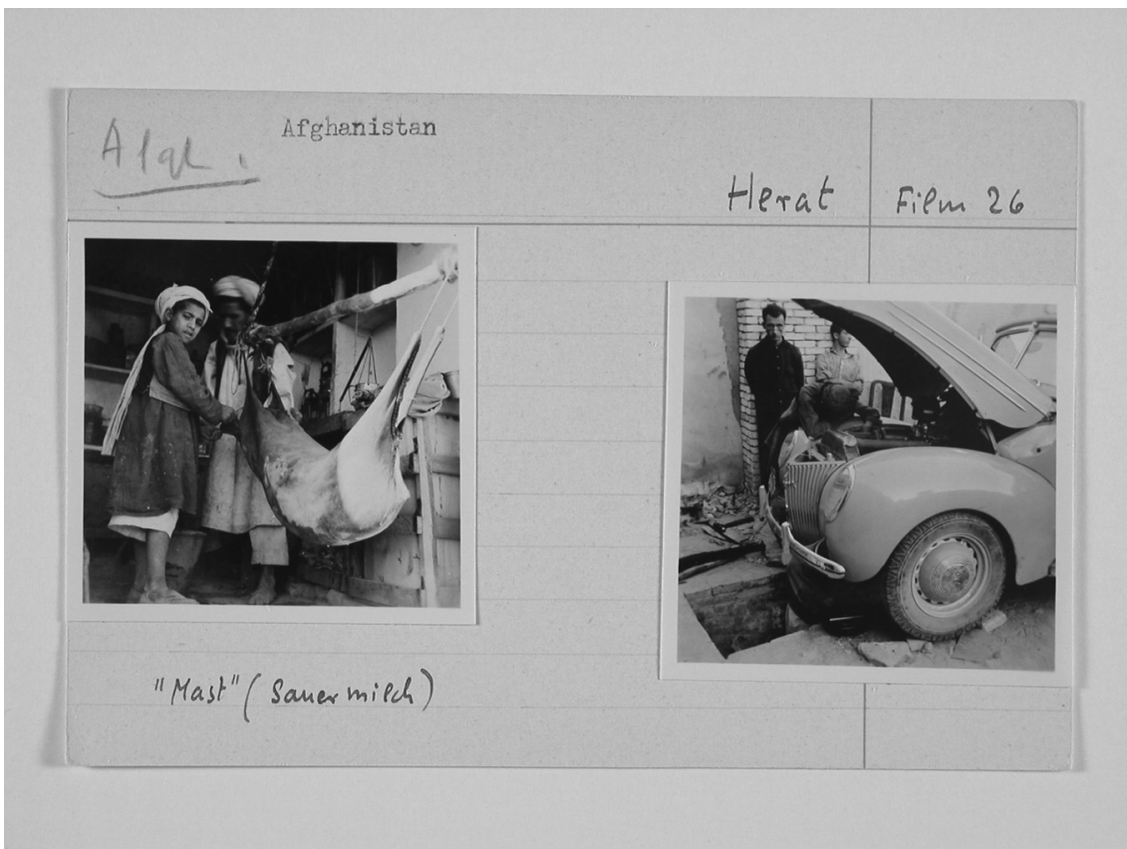

Fig. 5: Annemarie Schwarzenbach: Afghanistan, Herat: Basar (1939-40).

Schweizerisches Literaturarchiv, Nachlass Annemarie Schwarzenbach, Schweizerische Nationalbibliothek Bern, SLA-Schwarzenbach-A-5-19/186.

While the index cards work through montage, juxtaposing two (or more) photographs inside the same frame, these index cards are also part of larger structures within the photographic archive where they form series and can hence be approached through the lens of seriality and the specific practices it affords (Ruchatz). One example is a series of five photographs and two index cards showing the Gonbad-e Qabus burial tower in Iran (A-5-19/089; A-5-19/091; A-5-19/092; A-5-19/094; A-5-19/097; A-5-19/098; A-5-19/099) (figs. 7 and 8). The five photos present the burial tower from different angles and in the context of different local settings: One is a low-angle close-up of the tower, one shows it in the background of a small town, and three combine it with a camel in the foreground, facing in opposite directions. The two index cards juxtapose versions of the first two photographs with other images, once combining it with an image of a wall that seemingly needs repair, a man sitting on his heels in front of it likely engaged in that very task (the handwritten comment reads "Reparaturen;" A-5-19/089); and once adding a photo of a house, the car parked in the doorway, to which Schwarzenbach adds: "Das Haus des armen. Schnapshändlers, u. unsere Wohnung" (A-5-19/092).

Viewing the photographs of the Gonbad-e Qabus burial tower in series has some of the same effects as looking at the index cards. For here, too, 


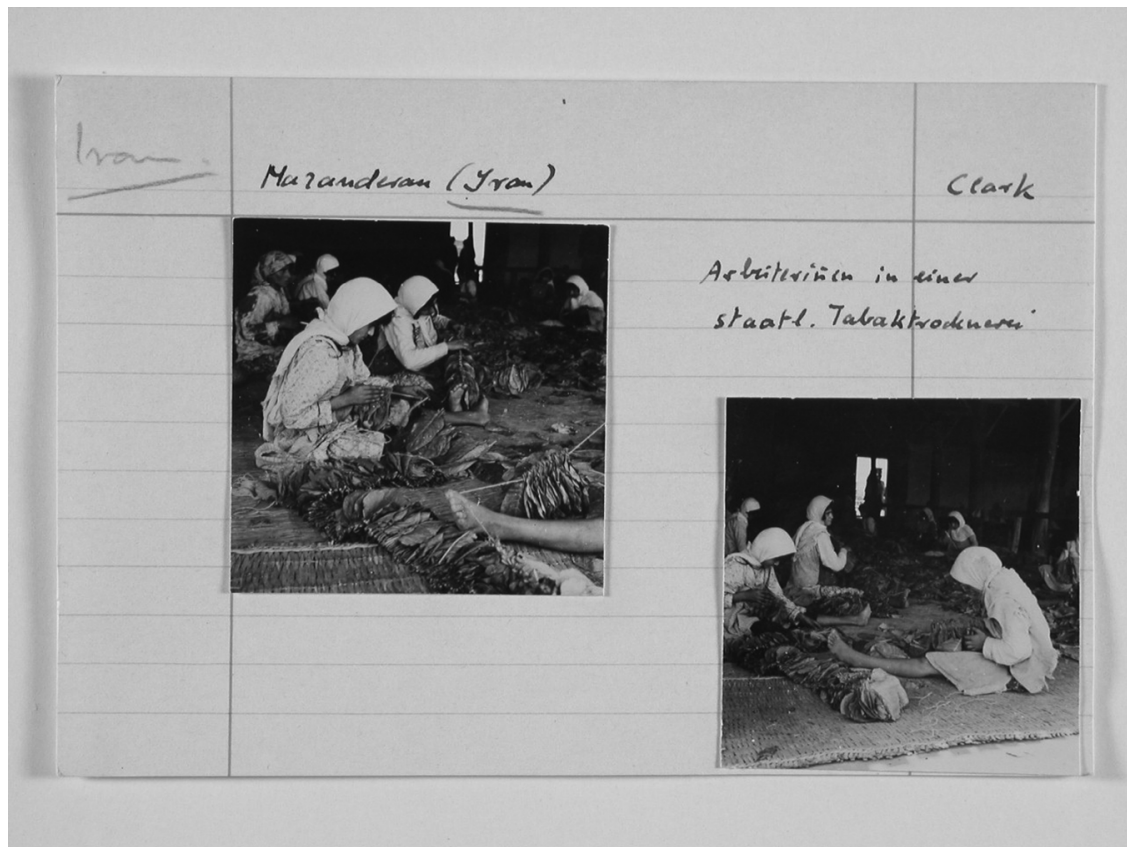

Fig. 6: Annemarie Schwarzenbach: Iran, Mazanderan (Mazandaran): Tabaktrocknerei (1939-40). Schweizerisches Literaturarchiv, Nachlass Annemarie Schwarzenbach, Schweizerische Nationalbibliothek Bern, SLA-Schwarzenbach-A-5-19/064.

movement is suggested when the tower is shown from different angles, with and without camel, the latter in its shifting position and distance creating an effect akin to the pre-cinematic technology of the flip-book. More importantly, however, the series possesses the particular affordance of unfolding a narrative across images and thus across space and time; its stories cannot be folded into a single image, just as it contains more than one narrative strand, or does away with narrative altogether. For not only do the multiple points of view present different realities by situating the tower differently, but watching the images in series also drives home the point that the reading of an image depends on its surroundings. In a series, there are multiple such surroundings. ${ }^{12}$ They constantly shift the photographic meaning, just as the series prompts viewers to pay attention to processes of repetition and selection.

Since the SLA archive holds all of the photographs Schwarzenbach had saved as part of her personal collection, ${ }^{13}$ it goes far beyond the selection of images that were published in photo-reportages during her lifetime and in the books that were edited posthumously. ${ }^{14}$ The kind of series the archive offers 


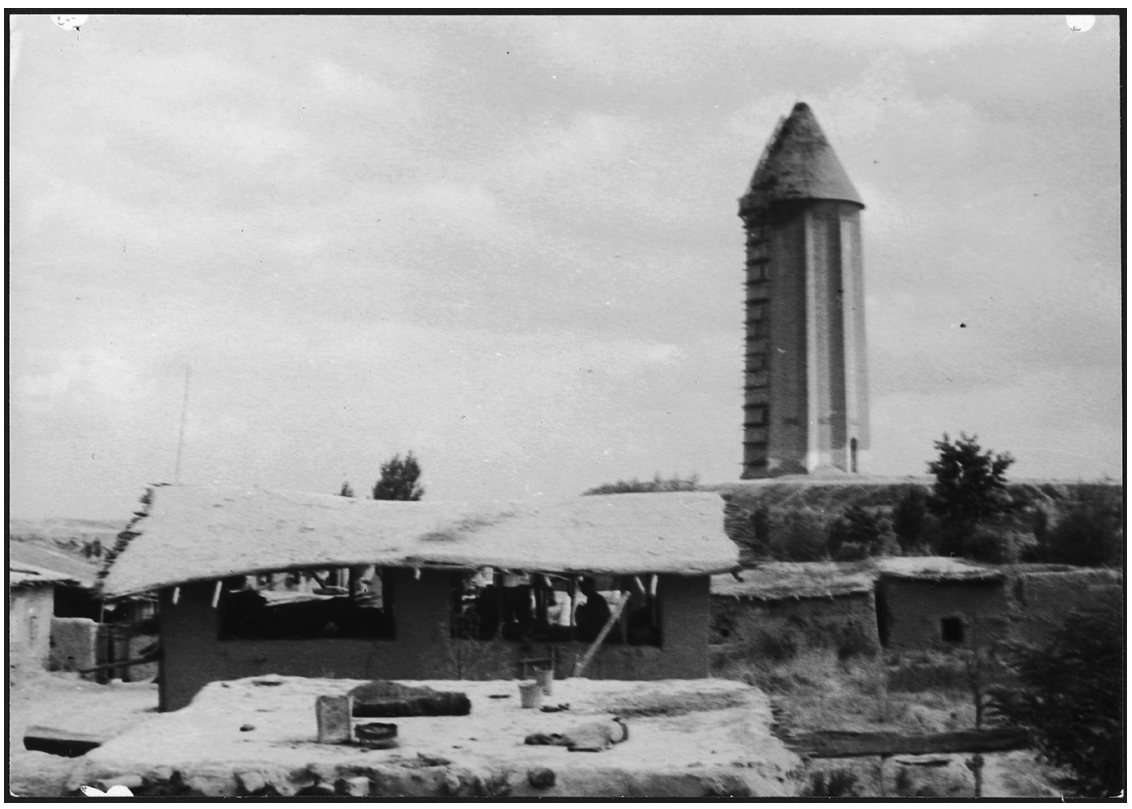

Fig. 7: Annemarie Schwarzenbach: Iran, Gumbad-i-Gabus (Gonbad-e Qabus, Gonbad-e Kabood): Grabturm (1939). Schweizerisches Literaturarchiv, Nachlass Annemarie Schwarzenbach, Schweizerische Nationalbibliothek Bern, SLA-Schwarzenbach-A-5-19/091.

can thus be called 'inadvertent' series. They enable a thinking and viewing in seriality that gives viewers insights into Schwarzenbach's practices, including her ever-shifting approaches to her subjects, expressed in multiple photos taken from slightly alternating points of view; her own archiving techniques, realized in the text-image combinations on index cards and envelopes; and her processes of evaluating and selecting photos for publication. Looking at the photographs in series, as they derive and emerge from the archival system of collecting and ordering, a small number of published images is joined by a far larger number of unpublished photographs. Together, they make the careful selection process discernable, which excluded options that may have deviated from the intended message and preferred aesthetic; they also allow us to re-integrate these once discarded outliers into 'our' reading of Schwarzenbach's photographic practice.

Drawing on the archival collection in this way, considering well-known motifs side by side with lesser-known motives, seeking connections between images, and probing Schwarzenbach's aesthetic through shifting constellations, an oeuvre and practice becomes discernable which is astonishing and unruly. Yet, it can be accessed through the archive, and with the six essays 


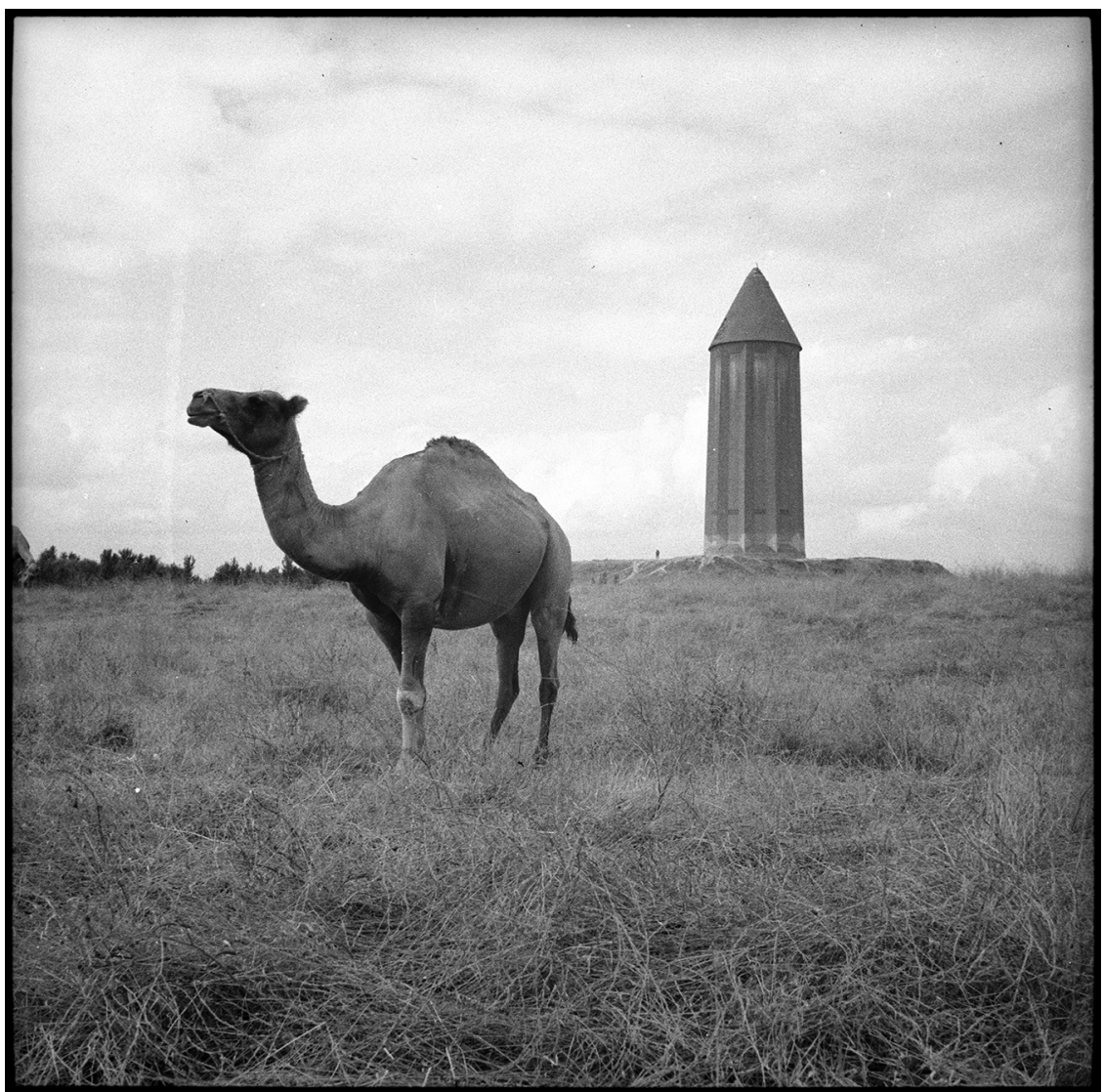

Fig. 8: Annemarie Schwarzenbach: Iran, Gumbad-i-Gabus (Gonbad-e Qabus, Gonbad-e Kabood): Grabturm (1939-40). Schweizerisches Literaturarchiv, Nachlass Annemarie Schwarzenbach, Schweizerische Nationalbibliothek Bern, SLA-Schwarzenbach-A-5-16/098.

that are presented in the following, we hope to contribute to such an opening of the Schwarzenbach archive, allowing readers and viewers to explore her photographs and their surrounding practices in their multiplicities and frictions.

\section{Acknowledgments}

We would like to thank the editors of Monatshefte-Sonja E. Klocke and Hannah Vandegrift Eldridge-for their interest and support, and the six authors-Moritz Wagner, Christina Natlacen, Elisaveta Dvorakk, Christiane 
Arndt, Kara Charles Felt, and Verena Kick-who have diligently and patiently worked with us under challenging conditions, as the issue came into being during the COVID-restricted times of 2020 and 2021. Also, Anna Maria Senuysal has been instrumental in carefully proofreading the manuscript and making sure it is consistent and accurate. Thank you!

${ }^{1}$ Especially the photos Marianne Breslauer took of Schwarzenbach have become iconic. Indicative of the tendency to focus on the figure of Schwarzenbach instead of her photographic practice is also the publication Der unbekannte Zwilling: Annemarie Schwarzenbach im Spiegel der Fotografien by Bettina Augustin that includes solely photographs of (and not by) Schwarzenbach. The same is true of the comparatively large number of biographies, including titles such as Areti Georgiadou: “Das Leben zerfetzt sich mir in tausend Stücke:” Annemarie Schwarzenbach: Eine Biografie; Charles Linsmayer: Annemarie Schwarzenbach: Ein Kapitel tragische Schweizer Literaturgeschichte; Dominique Laure Miermont: Annemarie Schwarzenbach ou le mal de l'Europe; Alexis Schwarzenbach: Auf der Schwelle des Fremden: Das Leben der Annemarie Schwarzenbach. Some of the first examples addressing Schwarzenbach's photographs include Katharina Sykora's essays “Außer Kurs: Zu den Reisefotografien von Marianne Breslauer, Annemarie Schwarzenbach und Ella Maillart” and "'Ein Bild ist erst gut, wenn sein Gehalt dem Betrachter sozusagen in die Augen springt:' Zum fotografischen Oeuvre von Annemarie Schwarzenbach;" the 1998 symposium Autorin - Reisende - Fotografin, resulting in the eponymous conference proceedings edited by Elvira Willems; and the exhibition Annemarie Schwarzenbach: The Dark Years 1937-1938 at the Swiss Institute - Contemporary Art in 2002.

${ }^{2}$ The holdings by Annemarie Schwarzenbach at the Swiss Literary Archive (SLA) can be accessed here: https://www.nb.admin.ch/snl/de/home/ueber-uns/sla/nachlaesse-archive/fokus/ schwarzenbach.html; see also https://commons.wikimedia.org/wiki/Category:CH-NB-Anne marie_Schwarzenbach; and https://www.e-manuscripta.ch/search/quick?query=schwarzenbach $\% 2 \mathrm{C} \% 20$ annemarie $\& \max =100 \&$ facets $=\mathrm{dr} 100 \% 3 \mathrm{D} \% 221900 \% 22 \&$ offset $=3401$.

${ }^{3}$ The digitization history of Schwarzenbach's photos is detailed in "Am Ende aller Wege / Au bout de tous les lointains. Annemarie Schwarzenbach Reisen / Voyages 1933-1942."

${ }^{4} \mathrm{We}$ are providing archival signatures that lead readers to some of Schwarzenbach's more contested photographs from Africa instead of reproducing one of these images here in order to avoid a reiteration of colonialist images and their connected imaginations. In Potential History: Unlearning Imperialism Ariella Aïsha Azoulay has suggested to think the colonial condition through the photographic shutter and to understand "the shutter [as] a synecdoche for the operation of the imperial enterprise altogether, on which the invention of photography, as well as other technological media, was modeled" (2).

${ }^{5}$ For a detailed analysis of Schwarzenbach's photographic treatment of Middle Eastern landscapes, including imaginary overlays between Afghanistan and Switzerland, aesthetic references to the Romantic tradition, and identifications between her body, self, and nature see the chapter "Steppen, Pässe, Täler: Naturmetapher und Sehnsuchtsbewegung” in Sykora "Ausser Kurs" (2001): 228-231.

${ }^{6}$ The Farm Security Administration (FSA), which ran from 1937 until 1946 was preceded by the Resettlement Administration in operation from 1935 until 1937.

${ }^{7}$ The Phalavi hat was introduced in 1927 by Reza Shah in an attempt to westernize Iran, in part by introducing European-style clothing. It had to be worn together with an Europeanstyle coat and trousers.

${ }^{8}$ See for the white gaze the foundational statement by Frantz Fanon: "And then the occasion arose when I had to meet the white man's eyes. An unfamiliar weight burdened me. The real world challenged my claims. In the white world the man of color encounters difficulties in the development of his bodily schema. [. . . ] The elements that I used had been provided for me not by 'residual sensations and perceptions primarily of a tactile, vestibular, kinesthetic, and visual character,' but by the other, the white man, who had woven me out of a thousand details, 
anecdotes, stories." (Fanon 83-84; for a further discussion of the white gaze in the American context see Yancy)

${ }^{9}$ Similar juxtapositions are quite common on Schwarzenbach's index cards, for instance when she combines photos of her car with photos of camels (A-5-20/150). A photograph showing the same man and boy producing "Mast," albeit from a slightly different angle, is juxtaposed on a second index card with a pond and a garden belonging to the site of pilgrimage in Gazer Gah (Sharif) (A-5-19/190).

${ }^{10}$ Schwarzenbach's interest in documentary film as a form of social critique and engagement is documented in her notes on the screenings of Joris Ivens films Nieuwe Gronden (1930) and Misère au Borinage (1934) she attended in Moscow in 1934 (see the essay by Dvorakk in this volume) and the stills from The River (1937), a film about the Mississippi, that were part of her collection and are thus part of her archival holdings (A-5-12/046).

${ }^{11}$ In The Civil Contract of Photography, Ariella Azoulay suggests the introduction of "the dimensions of time and movement into the act of watching stills [as] the foundation for the ethics of the spectator" (27).

${ }^{12}$ In her contribution to this issue, Verena Kick has referred to these kinds of surroundings, following Allan Sekula, as external discourses.

${ }^{13}$ The state of the Schwarzenbach archive is notoriously difficult, because not only did Schwarzenbach's mother, Renée Schwarzenbach-Wille, destroy some of her daughter's work after her death, but a number of the photographs are also not easily attributed to a specific author, as Schwarzenbach also included images by others in her personal collection.

${ }^{14}$ When Roger Perret started editing Schwarzenbach's collected writings for Lenos publishing in the late 1980s, he made the decision to include a selection of photographs with the journalistic travel writings, including Alle Wege sind offen: Die Reise nach Afghanistan 1939/ 1940; Auf der Schattenseite: Ausgewählte Reportagen, Feuilletons und Fotografien 1933-1942; Insel Europa: Ausgewählte Reportagen und Feuilletons 1930-1942; Jenseits von New York. Ausgewählte Reportagen, Feuilletons und Fotografien aus den USA 1936-1938.

\section{Works Cited}

Am Ende aller Wege / Au bout de tous les lointains. Annemarie Schwarzenbach Reisen /Voyages 1933-1942. https://ead.nb.admin.ch/web/appschwarzenbach/index.html [date of access, January 25,2021$]$.

Augustin, Bettina. Der unbekannte Zwilling: Annemarie Schwarzenbach im Spiegel der Fotografien. Berlin: Brinkmann und Bose, 2008. Print.

Azoulay, Ariella. The Civil Contract of Photography. New York: Zone Books, 2008. Print.

Azoulay, Ariella Aïsha. Potential History: Unlearning Imperialism. London, New York: Verso, 2019. Print.

Bergmann, Franziska. "'Seit Generationen hat die herrschende weisse Klasse ihre ganze [...] Anstrengung darauf gerichtet, die Suprematie der weissen über die schwarze Rasse zu erhalten. 'Annemarie Schwarzenbachs Fotoreportagen über die USA aus Perspektive der Critical Whiteness Studies." Annemarie Schwarzenbach: Werk, Wirkung, Kontext. Ed. Mirella Carbone. Bielefeld: Aisthesis, 2010. 279-290. Print.

Bettray, Ute. "An Ideological Framing of Annemarie Schwarzenbach's Racialized Gaze: Writing and Shooting for the USA-Reportagen (1936-38)." Sophie Discovers Amerika: GermanSpeaking Women Write the New World. Eds. Rob McFarland and Michelle Stott James. Rochester, NY: Camden House, 2014. 183-204. Print.

Decock, Sofie. "Zwischen Hoffnung und Fatalismus. Annemarie Schwarzenbachs Amerikareportagen." inside out. Textorientierte Erkundungen des Werks von Annemarie Schwarzenbach. Eds. Sofie Decock and Uta Schaffers. Bielefeld: Aisthesis, 2008. 193-209. Print.

Fanon, Frantz. Black Skin, White Masks. London: Pluto Press, 2008. Print.

Fotogeschichte. Beiträge zur Geschichte und Ästhetik der Fotografie, 37.144 (2017) (issue: Belichtete Vergangenheit. Archäologie und Fotografie, ed. by Babett Forster). Print.

Foucault, Michel. The Archaeology of Knowledge and the Discourse on Language. New York: Vintage Books, 2010. Print.

French, Lorely. "Gender, Rasse und soziale Schicht: Die Darstellung des Körpers in Annemarie Schwarzenbachs Fotografien und Aufsätzen aus den USA 1936-38." Annemarie Schwar- 
zenbach: Autorin - Reisende - Fotografin. Dokumentation des Annemarie Schwarzenbach Symposiums in Sils / Engadin vom 25. bis 28. Juni 1998. Ed. Elvira Willems. Herbolzheim: Centaurus Verlag, 2001. 2nd Edition. 185-207. Print.

Georgiadou, Areti. "Das Leben zerfetzt sich mir in tausend Stücke:" Annemarie Schwarzenbach: Eine Biografie. Munich: dtv, 1998. Print.

Heidemann, Frank: "Transkulturelle Bilder: Von der Kolonialfotografie zu ,dritten Bildern." journal-ethnologie.de (2005) (special issue: Visuelle Anthropologie). http://journalethnologie.de/Schwerpunktthemen/Schwerpunktthemen_2005/Visuelle_Anthropologie/ Transkulturelle_Bilder/index.html [date of access, January 09, 2021].

Henke, Silvia. "'Einen Haufen Elend als Sujet benützen?' Annemarie Schwarzenbachs implizite Fototheorie im Spannungsfeld von Rassismus und Aufklärung." inside out. Textorientierte Erkundungen des Werks von Annemarie Schwarzenbach. Eds. Sofie Decock and Uta Schaffers. Bielefeld: Aisthesis, 2008. 211-239. Print.

Hight, Eleanor and Sampson, Gary D. "Introduction: Photography, 'Race', and Post-Colonial Theory." Colonialist Photography. Imag(in)ing Race and Place. Eds. Eleanor Heigh and Gary D. Sampson, London, New York: Routledge, 2002. 1-19. Print.

Linsmayer, Charles. Annemarie Schwarzenbach: Ein Kapitel tragische Schweizer Literaturgeschichte. Frauenfeld: Huber-Verlag, 2008. Print.

Malinowski, Bronisław. Ein Tagebuch im strikten Sinne des Wortes, Neuguinea 1914-1918: Schriften in vier Bänden. Ed. Fritz Kramer, Frankfurt am Main: Syndikat, 1986. Print.

Massey, Heath. "Archeology of Knowledge: Foucault and the Time of Discourse." Understanding Foucault, Understanding Modernism. Ed. David Scott. New York, London, et al: Bloomsbury Academic, 2017. 79-94. Print.

Melone, Mirco. "Fotohistorische Rahmenbedingungen." Aufbruch ohne Ziel: Annemarie Schwarzenbach als Fotografin. Eds. Nina Zimmer and Martin Waldmeier. Zurich: Lars Müller Publishers, 2020. 120-131. Print.

Memoriav. Verein zur Erhaltung des audiovisuellen Kulturgutes der Schweiz. Bestand Annemarie Schwarzenbach. https://memoriav.ch/de/projects/bestand-annemarie-schwarzenbach/ [date of access, January 25, 2021].

Miermont, Dominique Laure. Annemarie Schwarzenbach ou le mal de l'Europe. Paris: Payot, 2004. Print.

Moholy-Nagy, László. Malerei. Fotografie. Film. Munich: Albert Langen Verlag, 1927. Print.

Müller, Heidy Margrit. "'Je serai Archéologue" - ein autofiktionales Lebenskonzept bei Annemarie Schwarzenbach." '. . . all diese fingierten, notierten, in meinem Kopf ungefähr wieder zusammengesetzten Ichs." Autobiographie und Autofiktion. Eds. Elio Pellin and Ulrich Weber. Göttingen: Wallstein, Chronos, 2012. 71-120. Print.

Ruchatz, Jens. "Ein Foto kommt selten allein: Serielle Aspekte der Fotografie im 19. Jahrhundert." Fotogeschichte. Beiträge zur Geschichte und Ästhetik der Fotografie, 1868/69 (1998) (issue: Fotografie und Apparatur: Bildkultur und Fototechnik im 19. Jahrhundert): 31-46. Print.

Schwarzenbach, Alexis. Auf der Schwelle des Fremden: Das Leben der Annemarie Schwarzenbach. Munich: Collection Rolf Heyne, 2008. Print.

Schwarzenbach, Annemarie. Alle Wege sind offen: Die Reise nach Afghanistan 1939/1940. Basel: Lenos Verlag, 2003. Print.

Schwarzenbach, Annemarie. Auf der Schattenseite: Ausgewählte Reportagen, Feuilletons, und Fotografien 1933-1942. Eds. Regina Dieterle and Roger Perret. Basel: Lenos Verlag, 1995. 2nd Edition. Print.

Schwarzenbach, Annemarie. "'Bilder als Dokumente': die Zeitschrift 'Life'." Auf der Schattenseite: Ausgewählte Reportagen, Feuilletons und Fotografien 1933-1942. Eds. Regina Dieterle and Roger Perret. Basel: Lenos Verlag, 1995. 2nd Edition. 14-15. Print.

Schwarzenbach, Annemarie. Insel Europa: Ausgewählte Reportagen und Feuilletons 1930 1942. Ed. Roger Perret. Basel: Lenos Verlag, 2008.

Schwarzenbach, Annemarie. "Interview ohne Reporter." Auf der Schattenseite. Ausgewählte Reportagen, Feuilletons und Fotografien 1933-1942. Eds. Regina Dieterle and Roger Perret. Basel: Lenos Verlag, 1995. 2nd Edition. 11-13. Print.

Schwarzenbach, Annemarie. Jenseits von New York. Ausgewählte Reportagen, Feuilletons und Fotografien aus den USA 1936-1938. Ed. Roger Perret. Basel: Lenos Verlag, 1992. Print. 
Swiss Institute - Contemporary Art. Annemarie Schwarzenbach: The Dark Years 1937-1938, 2002. https://www.swissinstitute.net/2001-2006/Exhibitions/2002_Lounge_Specials/2002_ Annemarie_Schwarzenbach/Schwarzenbach.htm [date of access, January 25, 2021].

Sykora, Katharina. "Außer Kurs: Zu den Reisefotografien von Marianne Breslauer, Annemarie Schwarzenbach und Ella Maillart." Fotogeschichte 13.48 (1993): 27-43. Print.

Sykora, Katharina. "Ausser Kurs: Zu den Reisefotografien von Annemarie Schwarzenbach." Annemarie Schwarzenbach: Autorin - Reisende - Fotografin. Dokumentation des Annemarie Schwarzenbach Symposiums in Sils / Engadin vom 25. bis 28. Juni 1998. Ed. Elvira Willems. Herbolzheim: Centaurus Verlag, 2001. 2nd Edition. 209-239. Print.

Sykora, Katharina. "'Ein Bild ist erst gut, wenn sein Gehalt dem Betrachter sozusagen in die Augen springt:' Zum fotografischen Oeuvre von Annemarie Schwarzenbach." Feministische Studien 11.1 (1993): 81-95. Print.

Sykora; Katharina. "Von sich aus ins Weite." Aufbruch ohne Ziel: Annemarie Schwarzenbach als Fotografin. Eds. Nina Zimmer and Martin Waldmeier. Zurich: Lars Müller Publishers, 2020. 133-141. Print.

Tagg, John. The Burden of Representation: Essays on Photographies and Histories. Minneapolis: University of Minnesota Press, 1993. 2nd. Edition. Print.

Waldmeier, Martin. "Annemarie Schwarzenbach als Fotografin." Aufbruch ohne Ziel: Annemarie Schwarzenbach als Fotografin. Eds. Nina Zimmer and Martin Waldmeier. Zurich: Lars Müller Publishers, 2020. 11-29. Print.

Wichor, Simone. '"Die dunkle Seite:' Selbstdarstellung und Entfremdung im Werk von Annemarie Schwarzenbach." Medien der Autorschaft: Formen literarischer (Selbst-)Inszenierung von Brief und Tagebuch bis Fotografie und Interview. Eds. Lucas Marco Gisi, Urs Meyer and Reto Sorg. Munich: Wilhelm Fink Verlag, 2013. 153-165. Print.

Wiegand-Stempel, Barbara. "Bilder schreiben."Aufbruch ohne Ziel: Annemarie Schwarzenbach als Fotografin. Eds. Nina Zimmer and Martin Waldmeier. Zurich: Lars Müller Publishers, 2020. 107-119. Print.

Willems, Elvira, ed. Annemarie Schwarzenbach: Autorin - Reisende - Fotografin. Dokumentation des Annemarie Schwarzenbach Symposiums in Sils / Engadin vom 25. bis 28. Juni 1998. Pfaffenweiler: Centaurus Verlag, 2001. 2nd Edition. Print.

Yancy, George. Black Bodies, White Gazes: The Continuing Significance of Race in America. Lanham, Boulder, New York, London: Rowman \& Littlefield, 2016. Print.

Zimmer, Nina and Waldmeier, Martin, eds. Aufbruch ohne Ziel: Annemarie Schwarzenbach als Fotografin. Zurich: Lars Müller Publishers, 2020. Print.

\author{
Svea Braeunert and Tanja Nusser \\ Department of German Studies \\ University of Cincinnati \\ P.O. Box 210372 \\ Cincinnati, $\mathrm{OH} 45221-0372$ \\ svea.braeunert@uc.edu \\ tanja.nusser@uc.edu
}

